\title{
Energieprijzen en emissiehandel
}

Edwin Woerdman, Oscar Couwenberg en Andries Nentjes

SAMENVATTING Elektriciteitsbedrijven maken windfall profits door gratis verkregen $\mathrm{CO}_{2}$-emissierechten. Deze windfall profits wil de Europese Commissie elimineren door de rechten te veilen. Dat elektriciteitsbedrijven windfall profits incasseren is echter economisch gezien geen probleem. Het gebruik van de gratis verstrekte emissierechten brengt immers kosten met zich mee, namelijk de alternatieve kosten (opportunity costs), verbonden aan het afzien van de verkoop van de rechten. Windfall profits vormen echter wel een politiek probleem, omdat aandeelhouders er rijker van worden. Veilen lost dat weliswaar op, maar introduceert ook nieuwe politieke problemen, bijvoorbeeld rond de verdeling van de opbrengsten en de concurrentie met bedrijven buiten het emissiehandelssysteem.

RELEVANTIE VOOR DE PRAKTIJK Dit artikel geeft inzicht in de invloed die emissierechten hebben op energieprijzen. We maken duidelijk dat gratis $\mathrm{CO}_{2}$-rechten kosten hebben, die tot uitdrukking moeten komen in bijvoorbeeld de elektriciteitsprijs. Ook laten we zien welke invloed energiemarktstructuur en overheidsbeleid hebben op de mate waarin die kosten worden doorberekend en daarmee op de waarde van bedrijven.

\section{Inleiding}

In 2003 heeft de Europese Unie (EU) Richtlijn 2003/87/EC aangenomen betreffende de broeikasgasemissiehandel. Deze markt is gestart in 2005. De richtlijn eist dat overheden de emissierechten tot 2012 grotendeels gratis toewijzen. De rechten worden, op basis van de historische emissies, gratis weggegeven aan vervuilers. Deze manier van toewijzing wordt grandfathering genoemd. Artikel 10 van de richtlijn bepaalt onder meer dat voor de periode 2008-2012 minimaal negentig procent van de rechten gratis dient te worden uitgegeven. De elektriciteitsproductie is als grootste sector in het systeem verantwoordelijk voor bijna een derde van het totaal aan gedekte emissies (COM, 2005).

In theorie is emissiehandel een adequaat instrument. Het begrenst de uitstoot door het gebruik van emissieplafonds, het hangt een prijskaartje aan vervuiling en het stimuleert innovatie, omdat dure, klimaatvriendelijke technologie dan opbrengsten genereert waardoor vrijgekomen emissierechten kunnen worden verkocht. Ondanks de toegenomen acceptatie van de emissiehandel in de EU, zijn sommige institutionele elementen nog steeds controversieel, met name het allocatiemechanisme en de hoogte van de emissieplafonds van de lidstaten.

Wat het allocatiemechanisme betreft heeft de beslissing om gebruik te maken van grandfathering geleid tot maatschappelijke verontwaardiging over de zogenoemde windfall profits (Ellerman en Buchner, 2007, p. 73). Econometrisch onderzoek heeft inderdaad bevestigd dat energieproducenten deels de marktwaarde van hun gratis verkregen $\mathrm{CO}_{2}$-emissierechten doorberekenen aan energieconsumenten (zie bijvoorbeeld Smale et al., 2006; Frontier Economics, 2006; Sijm et al., 2005). Kranten en tijdschriften in heel Europa hebben geschreven over de forse windfall profits die deze bedrijven dientengevolge zouden maken. Ook enkele economen hebben hun bezorgdheid geuit over die specifieke winsten (zie bijvoorbeeld Jepma, 2006). Wat de hoogte van de emissieplafonds betreft zijn de EUlidstaten bovendien royaal geweest in de toewijzing van de emissierechten, in elk geval in de periode 2005-2007 (zie bijvoorbeeld Ellerman en Buchner, 2006). Als gevolg hiervan is de roep om maatregelen tegen de windfall profits door emissiehandel nog luider geworden. Dit heeft aanvankelijk geleid tot een min of meer geharmoniseerde benadering binnen de lidstaten om relatief strenge emissieplafonds toe te wijzen aan de elektriciteitssector voor de periode 20082012. Meer recentelijk heeft de Europese Commissie voorgesteld om alle emissierechten te gaan veilen, vanaf 2012 aan elektriciteitsbedrijven en vanaf 2020 aan de overige sectoren in het systeem (COM, 2008).

Door de introductie van emissiehandel zou de markt ervoor zorgen dat $\mathrm{CO}_{2}$-emissies worden geprijsd, waardoor het duurder zou worden om te vervuilen. Hoe valt dit te rijmen 
met het feit dat volgens diverse onderzoeksrapporten en krantenartikelen vervuilers nu extra winst maken, door de waarde van de emissierechten door te berekenen in de elektriciteitsprijzen? Op het eerste gezicht oogt de verontwaardiging van consumenten terecht. Producenten hebben de rechten gratis ontvangen. Gratis emissierechten lijken dan niet als directe kosten in de kostprijs te moeten verschijnen. Maar zo simpel ligt het toch niet. Wij zullen aantonen dat gratis verstrekte emissierechten wel degelijk kosten met zich meebrengen en dat veilen, als alternatief, diverse nieuwe problemen introduceert.

In dit artikel beantwoorden wij de volgende centrale vraag: moeten energieconsumenten betalen voor de emissierechten die de energieproducenten gratis hebben gekregen? In de uitwerking en beantwoording van deze vraag, waartoe wij een eerste aanzet deden in Woerdman e.a. (2006), zullen wij ons voornamelijk toespitsen op de aanbodzijde. Uiteraard worden energieprijzen bepaald door zowel aanbod als vraag, maar wij richten ons grotendeels op de waarde en kosten van emissierechten als een van de productiefactoren die de aanbodcurve bepalen, omdat dit aspect recentelijk zoveel controverse heeft veroorzaakt.

Het artikel is als volgt ingedeeld. In paragraaf 2 gaan wij in op de economische consequenties voor energieprijzen van de zogenoemde opportunity costs van gratis emissierechten, uitgaande van elektriciteitsproducenten zonder marktmacht. In paragraaf 3 bezien we welke de beperkingen zijn bij het doorberekenen van opportunity costs. In paragraaf 4 analyseren we de economische gevolgen van alternatieve overheidsmaatregelen tegen de windfall profits die energiebedrijven maken, waaronder veilen. In paragraaf 5 schetsen wij de voor- en nadelen van veilen. In paragraaf 6 volgen onze conclusies.

\section{De rol van opportunity costs}

Het is economisch correct dat energieconsumenten betalen voor de rechten die energieproducenten gratis hebben gekregen. De reden is dat gratis emissierechten opportunity costs hebben (zie bijvoorbeeld Grafton and Devlin, 1996; Nentjes et al., 1995). In plaats van de gratis rechten te gebruiken, had het bedrijf ze kunnen verkopen tegen de huidige marktprijs. Als een energiebedrijf bijvoorbeeld elektriciteit verkoopt, wil het dit verloren alternatief gecompenseerd krijgen via de prijs van zijn product. Het 'consumeren' van het recht om uit te stoten bij het produceren van output, is dan ook een kostenpost voor het bedrijf. Als de producenten gemotiveerd dienen te worden om elektriciteit te blijven produceren en af te zien van het verkopen van die rechten, dan moeten de gemiste opbrengsten van een dergelijke verkoop gecompenseerd worden via de elektriciteitsprijzen.
Laten we het voorbeeld van de elektriciteitsproducenten verder uitwerken. We veronderstellen eerst dat deze producenten geen marktmacht hebben, waardoor ze de prijzen van elektriciteit en emissierechten als gegeven beschouwen. Stel dat voorafgaand aan de introductie van een systeem van verhandelbare emissierechten, op tijdstip $t=0$, de kostprijs van een eenheid elektriciteit $€ 65$ is, bestaande uit $€_{50}$ brandstofkosten, $€_{10}$ kapitaalkosten en $€_{5}$ arbeidskosten. De normale winst is $€ 5$. In evenwichtstoestand is de marktprijs voor een eenheid elektriciteit dan $€_{70}$ (exclusief indirecte belastingen en distributiekosten).

Met de introductie van een emissiehandelssysteem op tijdstip $t=1$ wordt de marktwaarde van de gratis emissierechten toegevoegd aan de kostenposten die via de elektriciteitsprijs moeten worden terugverdiend. Stel dat de marktwaarde van een emissierecht een prijsstijging van $€ 20$ op de elektriciteitsprijs impliceert. (Van de marktprijs van een emissierecht per eenheid $\mathrm{CO}_{2}$ leiden producenten een prijsstijging per eenheid elektriciteit af.) Inclusief de normale winst wordt de elektriciteitsprijs dan $€_{90}$ per eenheid elektriciteit (uitgaande van constante marginale en gemiddelde kosten). De marktwaarde van de emissierechten is dan volledig doorberekend aan de consumenten en de elektriciteitsproducenten krijgen de opbrengst die ze missen door af te zien van verkoop van emissierechten volledig vergoed.

In diens jaarverslag zal de producent een totale winst per eenheid elektriciteit rapporteren van $€_{25}$. Deze winst bestaat uit twee delen: ten eerste de opportunity costs van de emissierechten van $€ 20$ en ten tweede de normale winst van $€_{5}$. Dit is duidelijk een situatie waarin de rapportage van de resultaten in het jaarverslag afwijkt van de economische realiteit: er is slechts een economische winst van $€_{5}$, terwijl $€_{20}$ nodig is om te compenseren voor de opportunity costs van het gebruik van de emissierechten.

Sommigen verwarren windfall profits met winsten die ontstaan uit overallocatie, waardoor bedrijven meer (in dit geval gratis) emissierechten krijgen dan ze nodig hebben (zie bijvoorbeeld Cunningham, 2007, pp. 27-28). Overallocatie wordt echter alleen veroorzaakt door een zekere mildheid in het vaststellen van het emissiedoel, terwijl windfall profits juist uitsluitend ontstaan door de toewijzingsmethode van grandfathering. Ook met stringente doelen zullen elektriciteitsproducenten windfall profits maken, omdat ook dan de gratis emissierechten voor hen nog steeds opportunity costs met zich meebrengen. De periode 2005-2007 werd gekenmerkt door overallocatie, hetgeen de prijs van $\mathrm{CO}_{2}$-rechten toen flink drukte. Dit betekende lage opportunity costs per eenheid $\mathrm{CO}_{2}$, maar dat doet niets af aan de opportunity cost-redenering zelf. De periode 2008-2012 kent strengere emissieplafonds en zal dus hogere opportunity costs met zich meebrengen. 
Anderen stellen dat het onjuist is om de marktwaarde van gratis emissierechten door te berekenen aan consumenten (zie bijvoorbeeld Jepma, 2006, pp. 6-7). De overheid zou voorwaarden kunnen stellen aan die doorberekening. Consumenten moeten echter, zoals zojuist uitgelegd, betalen voor de emissierechten die de energieproducenten gratis ontvangen hebben, omdat juist het gebruik van die rechten opportunity costs met zich meebrengt. Het is economisch onjuist als die overheidsvoorwaarden onvolledige doorberekening van gratis emissierechten zou afdwingen. We vinden toch ook niet dat een boer die zijn land gratis heeft geërfd van zijn rijke grootvader, met een lagere melkprijs genoegen moet nemen dan de boer die zijn land in pacht heeft? We vinden evenmin dat de boer die het werk door betaalde loonarbeiders laat uitvoeren een hogere melkprijs verdient te ontvangen, dan de boer die de melk levert met inzet van de eigen, gratis beschikbare arbeid.

Twee of drie jaar voorafgaand aan de start in 2005 van emissiehandel besloot de Raad van Ministers om grandfathering in de EU te gebruiken om het beprijzen van $\mathrm{CO}_{2}$ acceptabel te maken voor de industrie en om de concurrentiepositie van de lidstaten te beschermen. Pas één of twee jaar na de start van dit systeem waren politici verbaasd dat elektriciteitsbedrijven windfall profits maken. Dit zou echter helemaal geen verrassing moeten zijn. Het gratis weggeven van emissierechten genereert extra middelen voor elektriciteitsproducenten, waardoor de financiële positie van hun aandeelhouders verbetert. De waarde van een aandeel stijgt, omdat het elektriciteitsbedrijf gratis een goed met een marktwaarde krijgt. Het is echter wel verrassend dat politici niet wisten (of deden alsof zij niet wisten) dat dit zou gebeuren. Al aan het eind van de jaren negentig schreef Bohm (1999, p. 21): 'Gratis allocation such as grandfathering [...] [implies] that these firms obtain windfall profits (as compared to not being given the permits gratis)'. Anders dan deze economische realiteit is de vraag of de waardestijging van elektriciteitsbedrijven maatschappelijk aanvaardbaar is. Daarover verschillen de meningen. Voorstanders wijzen op de noodzaak van grandfathering destijds voor de politieke acceptatie van emissiehandel. Tegenstanders wijzen op de huidige commotie rond grandfathering en pleiten bijvoorbeeld voor het veilen van de emissierechten. Verderop in ons artikel bespreken we de economische consequenties van deze en andere mogelijkheden om de windfall profits te bestrijden. Maar eerst bestuderen we het opvallende fenomeen dat de emissierechten in de praktijk slechts gedeeltelijk in de elektriciteitsprijs worden doorberekend.

\section{Beperkte doorberekening van emissierechten}

Als elektriciteitsproducenten verwikkeld zouden zijn in een concurrentiestrijd zoals bij volledige mededinging, dan zouden de opportunity costs van de gratis rechten uiteindelijk volledig worden opgenomen in hun productprijzen. Maar in de praktijk doen zij dit slechts in beperkte mate. Volgens berekeningen door Frontier Economics (2006) voor de Directie Toezicht Energie (DTe), nu Energiekamer, van de Nederlandse Mededingingsautoriteit (NMa) is de mate van doorberekening van emissieprijzen in de elektriciteitsprijzen ongeveer honderd procent in de spot market, maar slechts vijftig procent voor forward sales (zoals verkopen die werden gedaan in $2005 \mathrm{om}$ in 2006 geleverd te worden). Op basis van soortgelijke berekeningen concluderen Sijm et al. (2006) dat de doorberekeningniveaus varieren tussen de zestig procent en honderd procent. De belangrijkste verklaring hiervoor is de oligopolistische aard van de elektriciteitsmarkt (zie bijvoorbeeld Sijm et al., 2005, pp. 98-103).

We willen benadrukken dat een oligopolistische marktstructuur de opportunity cost-redenering niet ongeldig maakt. Het doorberekenen van de opportunity costs van gratis emissierechten aan consumenten is niet het gevolg van te weinig concurrentie op de energiemarkt, maar een gevolg van het grandfathering-ontwerp van het emissiehandelssysteem. In het doorberekenen van die kosten spannen de elektriciteitsproducenten dus niet samen, maar gedragen zij zich hetzelfde als bedrijven die zouden opereren in een volledig competitieve energiemarkt. De omvang van de doorberekening kan echter wel verschillen. We leggen hierna uit waarom.

Veronderstel eerst een volledig concurrerende elektriciteitsmarkt. Elke stijging in kosten (dus ook de opportunity costs van gratis emissierechten) leidt tot hogere marginale kosten, waardoor de aanbodcurve omhoog schuift. Als de vraag inelastisch is, leidt deze kostenstijging (zeg, $\Delta \mathrm{C}$ ) tot een verhoging van de elektriciteitsprijs (zeg, $\Delta \mathrm{P}$ ) van dezelfde omvang $(\Delta P=\Delta C)$. Bij een elastische vraag is de stijging van de elektriciteitsprijs echter kleiner dan de stijging van de kosten, omdat de vraag afneemt als de elektriciteitsprijs omhoog gaat $(\Delta \mathrm{P}<\Delta \mathrm{C})$.

In het geval van een oligopolistische elektriciteitsmarkt is de elektriciteitsprijs niet langer gegeven vanwege het beperkte aantal bedrijven. Daardoor worden ze gezamenlijk geconfronteerd met een aflopende marginale opbrengstencurve. Uitgaande van dezelfde aanbodcurve en elastische vraag als zojuist genoemd, leidt een zelfde kostenstijging dan tot een kleinere stijging van de elektriciteitsprijs in vergelijking met volledige mededinging. Met andere woorden: de opportunity costs van gratis emissierechten worden in een oligopolistische marktsituatie slechts deels gereflecteerd in een hogere elektriciteitsprijs. Dit heeft niets te maken met die opportunity costs, maar alles met de marktstructuur.

Een andere vraag is of de energiebedrijven de emissierechtenmarkt kunnen manipuleren om buitensporige winsten 
te maken. Dit lijkt niet waarschijnlijk. De emissierechtenmarkt heeft veel meer deelnemers dan de elektriciteitsmarkt: het EU-emissiehandelssysteem dekt ongeveer 12.000 installaties in 25 lidstaten, terwijl elektriciteitsproducenten verantwoordelijk zijn voor ongeveer dertig procent van de totale gedekte emissies (COM, 2005). Convery en Redmond (2007) hebben inderdaad geconcludeerd (op basis van de Herfindahl-Hirschman Index) dat het onwaarschijnlijk is dat de elektriciteitsproducerende sector marktmacht kan uitoefenen in de emissiehandelmarkt.

In het rapport van Frontier Economics (2006, p. 22) wordt nog een aantal andere redenen genoemd voor een beperkte doorberekening van de opportunity costs van gratis emissierechten. Een van deze redenen is dat de forward sales van energie voor het jaar 2005 twee of drie jaar eerder plaatsvonden, toen het emissiehandelssysteem nog niet operationeel was. Elektriciteitsbedrijven hadden destijds verwachtingen van de $\mathrm{CO}_{2}$-prijs die wellicht afweken van de feitelijke marktprijs bij inwerkingtreding van het systeem. Een andere reden is dat piekelektriciteitsprijzen zoveel hoger liggen dan de kostprijs, gezien de hoge vraag ernaar, dat het onmogelijk wordt de $\mathrm{CO}_{2}$-prijs waar te nemen in deze piekprijzen. Ook kunnen bepaalde brandstoffen gebruikt worden voor de energieopwekking, zoals biomassa, die geen $\mathrm{CO}_{2}$-emissies veroorzaken. Deze productie hoeft niet met $\mathrm{CO}_{2}$-emissierechten te worden gedekt en de prijs hoeft dan ook niet de opportunity costs te omvatten. Concurrentie met bedrijven die binnen de EU opereren, maar die buiten het emissiehandelssysteem vallen, beperkt ook de mogelijkheden om de opportunity costs van gratis rechten door te berekenen aan consumenten. In EUlidstaten met veel kerncentrales, zoals Frankrijk, of in landen met veel waterkrachtcentrales, zoals Zweden, is het voor centrales in die landen die fossiele brandstoffen verbruiken, onmogelijk om de $\mathrm{CO}_{2}$-kosten door te berekenen (Sijm et al., 2006). De productiekosten van de dominante opwekkingsvorm bepalen in eerste instantie de elektriciteitsprijs. Voor centrales die fossiele brandstoffen verstoken, is bij stijgende kosten de enige optie de elektriciteitsproductie te verminderen en eventueel deze te staken. Ook internationale concurrentie met bedrijven in landen buiten het EU-emissiehandelssysteem stelt grenzen aan het doorberekenen van de $\mathrm{CO}_{2}$-prijs aan consumenten. Dit is niet relevant voor de elektriciteitssector, aangezien er vrijwel geen elektriciteit wordt geïmporteerd van buiten de EU, maar wel voor bijvoorbeeld de aluminiumindustrie (Smale et al., 2006). Concurrenten buiten de EU (en dus buiten het emissiehandelssysteem) hebben immers geen opportunity costs die hun kostprijzen verhogen. Bedrijven binnen de EU zullen dan veelal niet in staat zijn de opportunity costs door te berekenen. Hun alternatief is om de productie te staken en hun rechten te verkopen. Als echter de kosten van stoppen (namelijk het verschil tussen de waarde bij liquidatie van de centrale en de waarde bij het continueren van de productie) groter zijn dan de opbrengsten van de verkoop van emissierechten, dan zullen deze producenten de productie continueren alsof de emissierechten geen opportunity costs met zich mee zouden brengen.

Het lijkt inderdaad onwaarschijnlijk dat producenten van bijvoorbeeld elektriciteit of andere consumptiegoederen daadwerkelijk de markt verlaten, niet alleen omdat het potentiële waardeverlies bij het liquideren van een centrale hoog is, maar ook omdat de meeste lidstaten van de EU hebben bepaald dat een producent zijn toegewezen emissierechten verliest als hij een installatie sluit. Alleen Nederland en Zweden staan gesloten installaties toe om hun emissierechten te houden tot het einde van de verplichtingperiode (Ellerman en Buchner, 2007, p. 76). De Europese Commissie beslist voor 2010 hoe an internationale concurrentie blootgestelde sectoren kunnen worden beschermd.

\section{Aanpakken van windfall profits}

Wat kunnen politici doen aan de windfall profits van elektriciteitsproducenten en andere deelnemers in het EUemissiehandelssysteem? Hierna analyseren we vier mogelijkheden: het verbieden van de doorberekening, het belasten van de winsten, het verlagen van de emissieplafonds en het veilen van de emissierechten.

\subsection{Verbieden van de doorberekening}

Stel dat politici de windfall profits willen aanpakken door een prijsstijging onmogelijk te maken voor de elektriciteitsproducent uit het hiervoor behandelde numerieke voorbeeld (zie paragraaf 2). Dit zou betekenen dat de marktwaarde (van $€ 20$ ) van de gratis verkregen emissierechten niet meer in de elektriciteitsprijs tot uiting mag komen. Het resultaat is dat de marktprijs wordt teruggeduwd (van $€_{90}$ op tijdstip t $=1$ ) naar $€_{70}$ op tijdstip $\mathrm{t}=2$, hetzelfde prijsniveau als voor de introductie van emissiehandel (op tijdstip $\mathrm{t}=\mathrm{o}$ ). In het Nederlandse systeem zal de producent dan overwegen zijn elektriciteitscentrale stil te leggen, en zo mogelijk te verkopen, en hij zal zijn emissierechten verhandelen. Door verkoop van de centrale krijgt hij zijn initiële investering terug (na afschrijvingen) en voor de emissierechten ontvangt hij $€_{20}$ per eenheid (niet-geproduceerde) elektriciteit. De producent is dan beter af dan als hij door zou gaan met de productie van elektriciteit. Per eenheid elektriciteit levert stoppen immers $€_{20}$ op, terwijl doorproduceren juist $€_{20}$ verlies betekent. Het gevolg van een dergelijk maximumprijsbeleid zou dus zijn dat producenten de markt verlaten, wat het aanbod van energie doet verkleinen. Het gevolg is dat een verbod op het doorberekenen van de opportunity costs van emissierechten uiteindelijk de voorzieningszekerheid bedreigt. 
Of elektriciteitsbedrijven inderdaad de markt zullen verlaten als de elektriciteitsprijs onder het niveau van hun kosten wordt gedwongen, hangt onder andere af van hun verwachtingen ten aanzien van toekomstige elektriciteitsprijzen, van prijzen voor tweedehands centrales en van de hoeveelheid jaren dat er nog rechten verkocht mogen worden. Zij zullen wellicht doorgaan met de productie, mogelijk op beperktere schaal, als zij een meer winstgevend prijsbeleid verwachten in de nabije toekomst, waarbij het doorberekenen van de opportunity costs van de emissierechten wel wordt toegestaan (bijvoorbeeld na 2012 in een mogelijk regime waarin alle emissierechten geveild worden). Een producent accepteert dan nu een verlies, omdat hij zijn positie wil behouden op een markt waar hij in de toekomst weer winst verwacht te maken.

\subsection{Belasten van de winsten}

Sommige politici hebben overwogen om de elektriciteitsproducenten te belasten voor de windfall profits die zij maken (waaronder een aantal sociaaldemocraten in Duitsland en het Verenigd Koninkrijk). Een windfall tax zou de windfall profits niet ex ante voorkomen, maar zou ze ex post belasten, waardoor deze winsten worden ontnomen.

Een windfall tax is echter niet eenvoudig te definiëren. Het impliceert dat een 'normaal' winstniveau van een elektriciteitsproducent objectief meetbaar is. Alles boven dat niveau is dan de te belasten windfall profit. Een dergelijke belasting zou producenten een prikkel geven deze winsten te verbergen in de kosten in hun jaarverslagen. De anpak van dergelijk gedrag vereist extra, complexe en mogelijk ook inefficiënte regulering.

De windfall tax bleek al spoedig politiek onacceptabel te zijn, nog afgezien van het feit dat artikel 10 van Richtlijn 2003/87/EC vereist dat de rechten voornamelijk gratis moeten worden toegewezen. De belasting impliceert juist dat de vervuilers moeten betalen voor de emissierechten, maar de industrie heeft het emissiehandelssysteem juist geaccepteerd omdat zij dan niet hoefden te betalen voor hun emissierechten.

\subsection{Versterken van de emissieplafonds}

Verscheidene politici stelden vervolgens voor om de elektriciteitsbedrijven tussen 2008 en 2012 een relatief streng emissiedoel op te leggen in vergelijking met de andere sectoren in het systeem (zoals de overheden van Nederland, Duitsland, België en het Verenigd Koninkrijk). Begin 2006 bleek namelijk dat de totale $\mathrm{CO}_{2}$-uitstoot ongeveer vier procent lager was dan het antal emissierechten dat aan de installaties was uitgedeeld voor 2005 (Ellerman en Buchner, 2006). Deze overallocatie is een bewijs dat de emissieplafonds voor de periode 2005-2007 niet streng genoeg zijn vastgesteld, deels door lobbyinspanningen van energie-intensieve industrieën, deels door de wens van politici om voorzichtig met het systeem te starten.

Een 'onderallocatie' van rechten voor elektriciteitsbedrijven voor de periode 2008-2012 hoeft het probleem van de windfall profits echter niet op te lossen. Een lager emissieplafond komt neer op een kleiner aanbod van emissierechten (in verhouding tot de vraag) en, daardoor, tot een hogere prijs van die rechten. Dit betekent dat het absolute niveau van de windfall profits niet hoeft af te nemen. Een en ander is mede afhankelijk van de toewijzing van rechten aan de andere installaties in het systeem. Indien voor deze installaties bijvoorbeeld een nog ruimere toewijzing zou worden gedaan, zal de prijs van een recht minder stijgen dan in een situatie waarin ook voor deze installaties een scherp plafond zou zijn gesteld. Dit zou de windfall profits voor de elektriciteitsproducenten overhevelen naar de andere energie-intensieve sectoren. De elektriciteitsprijs zou er niet door omlaag gaan als het totaal aantal rechten hetzelfde blijft, zeker niet als krap bemeten elektriciteitsproducenten rechten moeten gaan aankopen en dat doorberekenen aan de consument.

Sommige EU-lidstaten, zoals Nederland, hebben besloten om (een deel van) die rechten te herverdelen over de andere deelnemers in het systeem. De Nederlandse overheid wil 15 procent minder rechten toewijzen aan de elektriciteitssector voor de periode 2008-2012. Ze zal een derde van deze rechten aan anderen dan de elektriciteitsproducenten toewijzen en twee derde zal worden verkocht op de markt. De opbrengst van de verkoop zal naar de consumenten gaan. Hoewel door dit herverdelingsbeleid de prijzen van emissierechten niet zullen stijgen, zal het effect op de windfall profits van elektriciteitsbedrijven maximaal 15 procent zijn. De windfall profits zullen dus niet verdwijnen bij een lager emissieplafond. Dit is ook geen verrassing als men bedenkt dat niet overallocatie, maar grandfathering de oorzaak is van de windfall profits.

\subsection{Veilen van de emissierechten}

De zojuist genoemde plannen om de windfall profits vóór 2012 te beëindigen, zijn gedoemd te mislukken. Voor de periode na 2012 hebben overheden de mogelijkheid (meer) emissierechten te veilen. Als elke elektriciteitsproducent emissierechten moet kopen om zijn $\mathrm{CO}_{2}$-uitstoot te dekken, zoals de Europese Commissie voorstelt, impliceert dit additionele (out-of-pocket)kosten. De producenten zullen deze extra kosten doorberekenen aan de consument. Bovendien zullen producenten geen windfall profits meer rapporteren in hun jaarverslagen.

De kosten van de aankoop van emissierechten die producenten opnemen in hun productprijzen bij veilen, zijn voor consumenten gemakkelijker te accepteren dan het argument dat de opportunity costs van gratis rechten aan 
hen moeten worden doorberekend bij grandfathering. Door de rechten te veilen, zal de kapitaalschenking aan de aandeelhouders van energiebedrijven worden geëlimineerd en bij de overheid terechtkomen.

\section{Veilen als beste oplossing?}

Veilen elimineert de windfall profits, hangt een prijskaartje aan de marginale $\mathrm{CO}_{2}$-eenheid en geeft een prikkel om te innoveren (zie bijvoorbeeld Cramton en Kerr, 1998). Tot 2012 mag echter slechts tien procent van de emissierechten worden geveild; ten minste negentig procent moet gratis worden toegewezen volgens artikel 10 van Richtlijn 2003/87/EC. Als gevolg hiervan kan een verandering in het allocatieregime pas na 2012 plaatsvinden. De politieke ruimte daartoe is echter groter dan ooit. Gegeven het feit dat het emissiehandelssysteem nu juridisch vastligt en institutioneel is ingebed in alle lidstaten en bedrijven, kan het veranderen van het toewijzingsregime gezien worden als een relatief kleine stap. Bovendien heeft de Europese Commissie, zoals gezegd, begin 2008 in een ontwerp-richtlijn voorgesteld om alle emissierechten aan elektriciteitsbedrijven te gaan veilen vanaf 2012 en aan de overige sectoren in het systeem vanaf 2020 (COM, 2008).

In tegenstelling tot een op veilen gebaseerde emissiehandel, pleiten sommige economen voor een $\mathrm{CO}_{2}$-heffing. Een heffing impliceert ook dat energieproducenten niet langer windfall profits maken (zie Shapiro, 2007; Jepma, 2006). De prijsonzekerheid die inherent is aan markten, ook die voor $\mathrm{CO}_{2}$-emissierechten, verdwijnt dan grotendeels. In plaats daarvan treedt echter de onzekerheid of de emissiedoelen wel worden gehaald. Bovendien wordt de marktprijs voor $\mathrm{CO}_{2}$ dan ingeruild voor een centraal vastgestelde, administratieve prijs voor $\mathrm{CO}_{2}$. Dit alles betekent dat de Europese Commissie verwikkeld raakt in een moeizaam proces van het aanpassen van de heffing om het EU-emissiedoel te bereiken. Dit wordt verder gecompliceerd doordat de verwachte economische groei een gestage opwaartse bijstelling van de $\mathrm{CO}_{2}$-heffing noodzakelijk maakt. Elke keer dat de belastingverhoging nodig is om het emissiedoel te halen, kan weerstand en dus een lobbyinspanning van de industrie worden verwacht.

Veilen zal de windfall profits beëindigen, maar heeft helaas ook enkele nadelen. Los van de complexiteit van het veilingontwerp, zou veiling een 'secundair allocatiedebat' kunnen ontketenen door het allocatieprobleem te verschuiven naar de vraag hoe de veilingopbrengsten gebruikt moeten worden (Egenhofer en Fujiwara, 2005, p. 26). Moeten de opbrengsten herverdeeld worden onder de elektriciteitsproducenten als compensatie voor de kosten van hun klimaatmaatregelen, moeten de opbrengsten naar consumenten gaan ter compensatie van hun verhoogde energierekening of moeten de opbrengsten in de schatkist van de staat vloeien? En in dat laatste geval, moet de extra staatsopbrengst gebruikt worden om klimaatvriendelijke technologieën te financieren, om belasting op arbeid te verlagen, of om andere (niet-milieugerelateerde) sociaalwenselijke projecten te ondersteunen?

Uit een recent onderzoek onder 151 bedrijven in het Verenigd Koninkrijk bleek dat 75 procent van hen de overheidsfondsen verkregen uit milieuregulering, zoals een milieuheffing, het liefst besteed zou willen zien aan groene initiatieven (Manning en Howlett, 2007, p. 15). Het moge duidelijk zijn dat diverse groepen belanghebbenden - energieproducenten, aanbieders van alternatieve groene technologie, consumentenorganisaties - zich zullen inspannen de keuze van de overheid voor een bepaald bestedingsdoel te sturen. Het voorstel van de Europese Commissie is om ten minste twintig procent van de opbrengsten te earmarken voor klimaatvriendelijke projecten, waaronder hernieuwbare energie en $\mathrm{CO}_{2}$-opslag (COM, 2008, pp. 22-23).

Dit probleem van wat te doen met de opbrengsten van de veiling moet niet lichtzinnig aan de kant worden geschoven. Het vergelijkbare probleem, namelijk wat te doen met de opbrengsten van een $\mathrm{CO}_{2}$-heffing, verklaart deels waarom een dergelijke belasting uiteindelijk werd verworpen. Commissielid Jos Delbeke, ontwerper van een $\mathrm{CO}_{2}$-heffingvoorstel in de jaren negentig, zei in een interview: 'The level of the tax was quite significant. And that was part of the problem. [...] It's very difficult to discuss a tax measure. It's even more difficult to agree on what to do with the revenues' (in: Jones, 2007, p. 2). Een voorstel om de emissierechten te veilen zou in de politieke arena om dezelfde reden kunnen sneuvelen.

Een ander probleem met veilen is dat het de net cash flow verslechtert van EU-bedrijven die te maken hebben met concurrentie van buiten het emissiehandelssysteem, zoals de aluminiumindustrie. Zoals hiervoor werd gesteld, zullen deze bedrijven niet in staat zijn om de kosten van de emissierechten door te berekenen aan hun klanten. Hun net cash flow zal afnemen met een bedrag dat gelijk is aan de kosten van de geveilde emissierechten (na belastingen). Dit zal het financieel weerstandsvermogen van de desbetreffende bedrijven uithollen en hen minder bestand maken tegen economische schokken. De voorgestelde richtlijn voorziet weliswaar in tijdelijke uitzonderingen voor nog nader te bepalen industrieën, maar de commissie wil uiteindelijk vanaf 2020 aan alle deelnemers de emissierechten veilen.

\section{Conclusies}

Emissiehandel is effectief door het gebruik van emissieplafonds. Bovendien is emissiehandel efficiënt, omdat vervuilers geconfronteerd worden met de schade en dus de kosten die de uitstoot van $\mathrm{CO}_{2}$ met zich meebrengt. Elke 
eenheid $\mathrm{CO}_{2}$ heeft nu immers een prijs: ofwel de prijs van het aankopen van emissierechten ofwel de opportunity costs van het gebruiken van de rechten. Tevens geeft emissiehandel een prikkel om te innoveren aangezien dure, klimaatvriendelijke technologie nu ook opbrengsten genereert waardoor vrijgekomen emissierechten kunnen worden verkocht.

Elektriciteitsbedrijven in het EU-emissiehandelssysteem worden ervan beschuldigd dat zij windfall profits maken. Wij hebben laten zien dat het doorberekenen van gratis emissierechten in energieprijzen economisch correct is. Gratis emissierechten brengen kosten voor bedrijven met zich mee, namelijk de opportunity costs van de rechten als ze gebruikt worden om de emissies te dekken. In plaats van de emissierechten te gebruiken had het bedrijf die rechten ook kunnen verkopen. Deze kosten zijn onderdeel van de kostprijs en moeten dus opgenomen worden in de energieprijs. Een elektriciteitsproducent zal zijn emissierechten alleen dan niet verkopen, als hij de verloren opbrengst kan terugverdienen via de elektriciteitsprijs.

In de praktijk vindt die doorberekening slechts in beperkte mate plaats, als gevolg van de oligopolistische structuur van de elektriciteitsmarkt. Een kostenstijging leidt dan tot een relatief kleine stijging van de elektriciteitsprijs, omdat de elektriciteitsprijs niet langer gegeven is zoals bij volledige mededinging. Dit maakt de opportunity cost-redene- ring niet ongeldig. Het doorberekenen van de opportunity costs is simpelweg het gevolg van het ontwerp van het EUemissiehandelssysteem, dat is gebaseerd op gratis toewijzing van emissierechten.

Windfall profits ontstaan bij gratis emissierechten, omdat energiebedrijven een kapitaalschenking krijgen die hun aandeelhouders rijker maakt. Dit is geen verrassing, maar een economisch feit dat al jaren bekend is in de literatuur. In die zin zijn windfall profits een politiek probleem, geen economisch probleem. Omdat tot 2012 veilen slechts zeer beperkt is toegestaan, kunnen de aandeelhouders van energiebedrijven nog enkele jaren genieten van de financiële voordelen van gratis emissierechten. Het debat over windfall profits zal pas volledig verstommen als de EU veilen introduceert voor de periode na 2012. De discussie zal zich dan vooral richten op de vraag welke besteding de overheid moet kiezen voor de veilingopbrengsten.

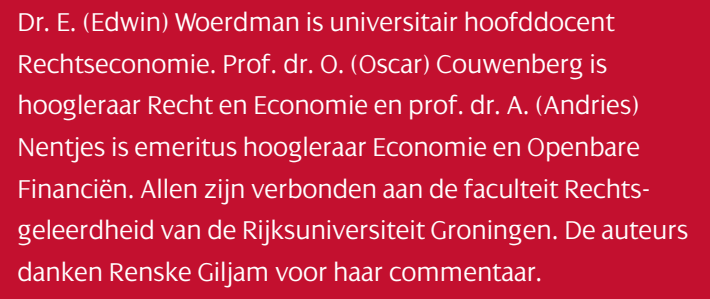

\section{Literatuur}

- Bohm, P. (1999), International greenhouse gas emission trading - With special reference to the Kyoto Protocol, TemaNord 1999, p. 506, Stockholm: Department of Economics. - COM (2008), Proposal for a Directive of the European Parliament and of the Council Amending Directive 2003/87/EC so as to Improve and extend the greenhouse gas emission allowance trading system of the Community, 2008/0013 (COD), 23 January 2008, Brussels: European Commission; zie: http://ec.europa.eu/environment/climat/ emission/pdf/ets_revision_proposal.pdf. - COM (2005), EU Action against climate change: EU emissions trading - An open scheme promoting global innovation, Brussels: European Commission; zie: http://ec.europa. eu/environment/climat/pdf/emission_ trading3_en.pdf.

- Convery, F.J. en L. Redmond (2007), Market and price developments in the European Union emissions trading scheme, Review of
Environmental Economics and Policy, vol. 1, no. 1, pp. 88-111.

- Cramton, P. en S. Kerr (1998), Tradable carbon permit auctions: How and why to auction not grandfather, Discussion Paper 98-34,

Washington DC: Resources for the Future (RFF).

- Cunningham, J. (2007), Carbon jackpot, Professional Engineering, 7 March 2007, pp. 27-28.

- Egenhofer, C. en N. Fujiwara (2005), Reviewing the EU emissions trading scheme: Priorities for short-term implementation of the second round of allocation (Part I), Brussels: Centre for European Policy Studies (CEPS); zie: http://shop.ceps.eu/BookDetail.php?item_ id $=1288$.

- Ellerman, A.D. en B.K. Buchner (2007), The European Union emissions trading scheme: Origins, allocation, and early results, Review of Environmental Economics and Policy, vol. 1, no. 1, pp. 66-87.

- Ellerman, A.D. en B. Buchner (2006), Over-allocation or abatement? A preliminary analysis of the EU ETS based on the 2005 emissions data, Nota di Lavoro 139.2006, Milan: Fondazione Eni Enrico Mattei (FEEM); zie: http://web.mit.edu/globalchange/www/ MITJPSPGC_Rpt141.pdf.

- Frontier Economics (2006), $\mathrm{CO}_{2}$ trading and its influence on electricity markets, Final Report for DTe, London: Frontier Economics Ltd.; zie: http://www.ez.n//dsresource?objectid=12907 $3 \&$ type $=$ PDF.

— Grafton, R.Q. en R.A. Devlin (1996), Paying for pollution: Permits and charges, Scandinavian Journal of Economics, vol. 98, no. 2, pp. 275-288.

- Jepma, C. (2006), Some EU ETS 'tags', (Electronic) Joint Implementation Quarterly: Magazine on the Kyoto Mechanisms, August, pp. 1-7.

- Jones, C. (2007), Grasping for air, International Tax Review, May 2007, pp. 1-8.

- Manning, J. en N. Howlett (2007), Saving the planet - Can tax and regulation help?, July 2007, PricewaterhouseCoopers; zie: https:// 
globalvatonline.pwc.com/uk/tls/gvol2/gvol2. nsf/AllByCode/RJAI-76JGWW?opendocument.

- Nentjes, A., P. Koutstaal en G. Klaassen (1995), Tradeable carbon permits: Feasibility, experiences, bottlenecks, Dutch National Research Programme on Global Air Pollution and Climate Change (NRP), NRP Report no. 410100 114, Groningen / Bilthoven: RuG / NRP.

- Shapiro, R.J. (2007), Addressing the risks of climate change: The environmental effectiveness and economic efficiency of emissions caps and tradable permits, compared to carbon taxes, February 2007, Washington DC: Sonecon.

- Sijm, J., K. Neuhoff en Y. Chen (2006), CO, cost pass-through and windfall profits in the power sector', Climate Policy, vol. 6, pp. 49-72. - Sijm, J.P.M., S.J.A. Bakker, Y. Chen, H.W. Harmsen en W. Lise (2005), CO2 price dynamics: The implications of EU emissions trading for the price of electricity, ECN-C-05081, September 2005, Petten: Energieonderzoek Centrum Nederland (ECN): zie: http://www.ecn.nl/fileadmin/ecn/units/ bs/Extra/CO2_price_dynamics.pdf.

- Smale, R., M. Hartley, C. Hepburn, J. Ward en M. Grubb (2006), The impact of $\mathrm{CO}_{2}$ emissions trading on firm profits and market prices, Climate Policy, vol. 6, pp. 31-48.

- Woerdman, E., O. Couwenberg en A. Nentjes (2006), Terechte energieprijsverhoging door gratis emissierechten, Economisch Statistische Berichten (ESB), vol. 91, no. 4493,

pp. 427-429. 